\title{
The Application of an Eco-Innovative Concept for Creating an Integrative Gene Banks in Animal Science and Production
}

\author{
Marcel MATIUTI ${ }^{* 11}$, Alexandru T. BOGDAN ${ }^{2)}$ and Carmen MATIUTI ${ }^{33}$ \\ ${ }^{1)}$ Faculty of Veterinary Medicine Timisoara, Romania \\ ${ }^{2)}$ Romanian Academy Bucharest, INCE, CSCBAS, Romania \\ 3)Technical College Azur Timisoara, Romania \\ *Corresponding author, email: matiutimarcel@yahoo.com \\ Bulletin UASVM Animal Science and Biotechnologies 71(2) / 2014, \\ Print ISSN 1843-5262; Electronic ISSN 1843-536X \\ DOI: $10.15835 /$ buasvmcn-asb:10800
}

\begin{abstract}
The zoogenetic patrimony includes the existence of gene banks, breeder's associations, family farms, niche market, cultural identity. It is crucial that an integrative gene bank be created on the territory of Romania. A relatively simple model of a gene bank is the so-called animal bank for DNA. It is necessary for Romania to quickly create a project for financing a Scientific Consortium for Transborder Coordination, for example in Banat, covering both the Romanian and the Serbian side based on eco-bio-geo-ethozootechny.
\end{abstract}

Keywords: Eco-Bio-Geo-Ethnozootehny, Farm DNA Bank, gene and genomic Banks

Introduction. Supporting zoogenetic biodiversity is very important for Romania's population in what regards its food safety. This biodiversity is maintained through preserving all the zoogenetic resources in the Carpathian-Danubian territory.

Aims and objectives. The zoogenetic patrimony can be protected in many ways. These include the existence of gene banks, breeder's associations, family farms, niche market, and cultural identity. The zoogenetic diversity contributes to diminishing rural poverty in all the country's regions.

Materials and methods. The paper is based on the data gathered from the Transylvanian Rare Breeds (TRB) Association and from the results obtained by the Study and Research Center for Agro-forestry Biodiversity "Acad. D. Davidescu" from the Romanian Academy, center which created the gene bank for scrapie in sheep and goats in 2010 on the occasion of the Annual DAGENE Symposium held at Brazi (Hateg). Also, the TRB Association supported the foundation of the only gene bank for birds in the west of Romania.
Results and discussion. It is crucial that an integrative gene bank be created on the territory of Romania, as well as of some pilot zootechnic state farms (Fig. 1). The existent farms of the specialized institutions or the research centers have been abandoned or are deprecating very fast. A relatively simple model of a gene bank is the so-called animal bank for DNA. Such a model exists in Austria for preserving the Mangalitza pig breed, which is being raised in several family farms, in numbers of 4-5 specimens. All pigs have pedigree and the DNA samples can be easily taken. This organization of Mangalitza Gene Bank was presented by Beate Berger and Fischeleitner F. (researchers at the Institute for Organic Farming and Biodiversity of Farm Animals in Thalheim Austria) in the ONGENE-DAGENE Conference Irdning (Austria) in 2007. As described by the two specialists in animal genetics when it building a Farm Animal DNA Bank (FADNAB) choosing the donor animals is made after pedigree, phenotype and traits productions. The artificial insemination in Al Center will be made testing, collection and storage of semen. In situ conservation can be 


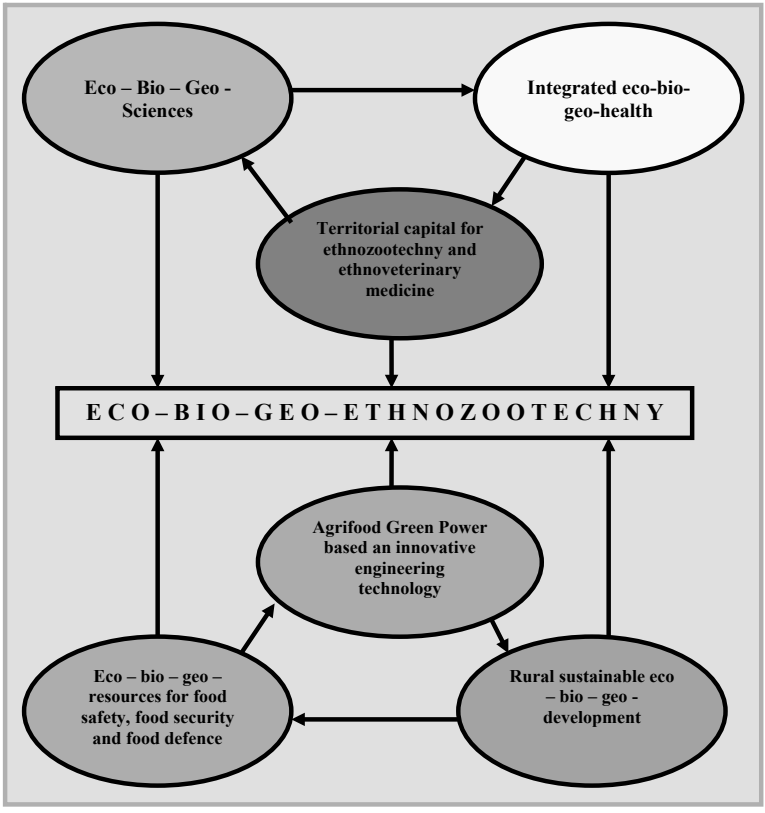

Fig. 1. The application of an eco-innovative concept for creating an integrative gene and genomic Banks for eco-bio-geo-ethnozootechny (orig.)

successful if program is clearly structured and controlled closely and if subsidies are linked to breeding and recording activities (Berger and
Fischeleitner, 2007). In Hungary, the organization of the gene banks for Mangalitza is different. There is a national association that holds the original cards of all Mangalitza pigs. The selection is made only on the male pigs line, which are the property of the association. The tested male pigs are distributed to the production farms so there is a control of their production (Matiuti and Matiuti, 2010).

Conclusion. The TRB Association considers that it is necessary for Romania to quickly create a project for financing a Scientific Consortium for Transborder Coordination, for example in Banat, covering both the Romanian and the Serbian side based on eco-bio-geo-ethozootechny.

\section{REFERENCES}

1. Berger B and Fisherleitner F (2007). Gene banking in rare and traditional pig breeds in Austria with special regard of Mangalica semen in conservation breeding, www. raumberg-gumpenstein.at/...mangalica.../16159-

2. Matiuti M and Matiuti C (2010). The necessity of gene Bank in order to protect the breeds created on Romanian territory, The $35^{\text {th }}$ annual Congress of the American Romania Academy of Art and Sciences Univ. Politechnica Timisoara, Proceedings Ed. Presses Internationales Polytechnique Montreal Quebec, 19-132. 